\title{
STUDIES ON RETARDED DEVELOPMENT OF SPEECH
}

Third Report: Incidence, Causes and Symptoms of Retarded Development of Speech in Threee-year-old Children.

\author{
By \\ Yoshisato TANAKA
}

From the Department of Otolaryngology, Faculty of Medicine Shinshu

University, Matsumoto. (Director: Prof. T. Suzuki)

Incidence, causes and symptoms of retarded development of speech were studied in 1114 children just three years old living in Matsumoto City, and the following results were obtained:

(1) Out of a total of 1114 children,

$\begin{array}{lr}\text { Congenital deafness } & 1 \text { case } \\ \text { Mental defficiency without hearing } & \\ \text { impairment and suspicious cases } & 6 \text { cases } \\ \text { Cerebral palsy } & 2 \text { cases } \\ \text { Retarded development of speech without }\end{array}$

Retarded development of speech without

\author{
mental defficiency as well as hearing \\ impairment \\ 30 cases \\ Stuttering \\ 13 cases
}

(2) Children of low birth weight were found more frequently in the group of retarded development of speech than in the normal group, and this was statistically significant.

(3) Neonatal asphyxia was also significantly frequent in the group of retarded development of speech.

\section{言語発達障害児の研究}

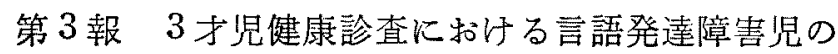
発生頻度とその原因及び症状の観察

信州大学医学部耳鼻咽诶科学教室（主任：鉿木黛郎敬授）

田 虫 美郷

\section{楮 贯}

小児の難聴や言語障書に関する調査はこれ迄主として 学童を対象に行われ，本邦に扎いては難聴に関しては豊

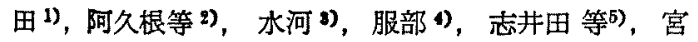
岛6)による活か幾多の報告》があり，言語障害につい

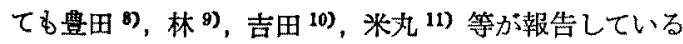
が，幼児を対象にした調查は殆どない，著者は最近松本 保健所の好意により 3 才贸における言語障害の発生頻度 やとの他若干の項目について調べる機会を得たが，3才 前後は言語発達の最も著しい時期であるからこの時期に 難聴や精神発達障害, 言語器官の異常, その他の身体的 久陒，並びに環境及び教育上の過誤等言語発達に革带的 影を及賃す要因を発見し，道切な奶策をたてること
は大きな意義があると考克，3才に達したばかりの小罗 1114 名について言語障害の害態を調べてみた。その結 果若干の知見を得たのでここに報告し御批判をあおく就 第である。

\section{険查対象}

昭和 36 年度以来照至福社法の一部改正以其ついて 3

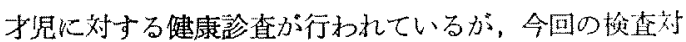

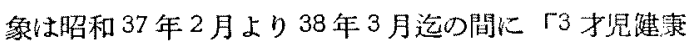
診查」のために松本保健所へ集つた満了才に達したばか b（即ち満 3 才 1 力月迄）の奻罗 1114 名（男578名， 女536名)である。

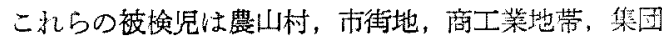
住宅地等の出身者であり，又それらの属する社会階層も 
粎々でする。

なお本調查は每月1回松本保健所に和いて行和れた が，残念な事に該当児が每月平均して 200 各位あつたに

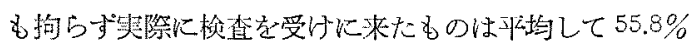

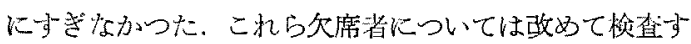
る機会学持ら得なかつたが，その等をみると交通の比

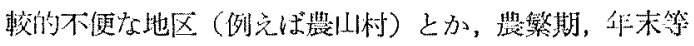

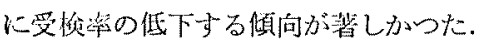

\section{検查方法及び診断基準}

1 梌查方法

検笪はすべて著者 1 人で行つたが，短時間に大勢を検 查しなくてはならない点からして愉查用具は殆ど用い ず，親の供述及び被换児との問答を主体として䜌断を下 した。な叔既往磨は母子手帳より調べ出した。

II診断基準

誩烦に当つては下記の如き検查項目を設定して使用し た.

1)呼えでる振向かない，音に警かない。

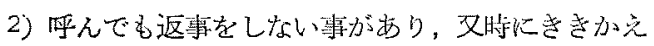
す事办市る。

3) 全くしやべれない.

4) 1 語文しわ話せない。

5) 2〜3語文性話すが笔文体である。

6) 自分の氏名加小党ない。

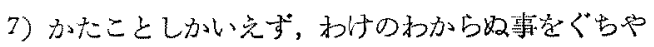
ぐちやいら.

8）発音が琶く，他人にはよく通じない(乎親が通訳 しないとわからない).

9）拉話がよくできないので手ま放をまじ光る。

10)こちらのいう事はよく理解できて行動する（例吕 ば「何才ですか?．怔としを指で示しなさい」等 ができる).

11）赤青の色の区別がでさる.

12）本をひとりで長い間てて楽しも.

13）上下又は前後といらことばの意味がかかる。

14）「ボク」「ワタシ」などの1人称代名詞を使う。

15) 自分の性 (sex) がわかる。

以上の項目は主に牛島氏等 12) 中津守・稲毛氏 ${ }^{13)}$ に よる精神発暹検查法や Gesell の発達診断学 14) その他

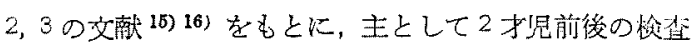
項目を中心に組立てたものである．1）2）の項目は蜼聴 の判別に，10)〜15) (精神発達程度の判定の指祭上し た，即ら難㯖が否定できて 10)〜13）の梌查項回ができ

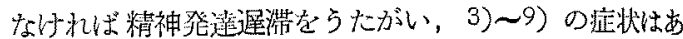
るが，10)〜15) がでされば精神発達痋滞は一地ない むのとした。項目 14) 以津守・稻毛 13) が，又15は

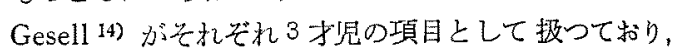
3才思以上でないと正答率が琹いが，著者の調べた範目 でも3报達したばかりではその意味がかかつて答党ら

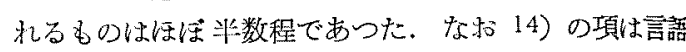
発達遅渵児であ，ことばが短かくて発音し易いためかて の意味がかかつて使えるもの（自分の氏名はいえない が、「ボク」存「ボ」とか「カク」とか発音する等)が しぱしば見受けられた。

\section{険查結果}

上百の才法はいわば言語障害見を選別するための1種 のスクリーニングテストである．彷つて言語障害の程度 や原因を知るためにはここに得られた結果たけでは信頼 性に限界があるので異常がうたがわれる場合には我々の 「奻見蚛力相談室」で梌查を受けるよら程力すするた。

しかし乍ら奏際に我々のところを訪れたのはこれ迄5名 にすぎない(第2表)。

\section{I 難 聴 㫛(第1 表)}

先才難聴のらた方われたものは3名（男2,女1）市

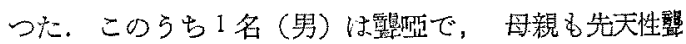
であつて遗伝性と将えら机る。他の2 名は呼てでる返事 をしない赫かがあり，雉聴ではないかとうたがわれる程 度で言語障害は伴つていなかつた。

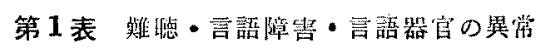
精种障墨等

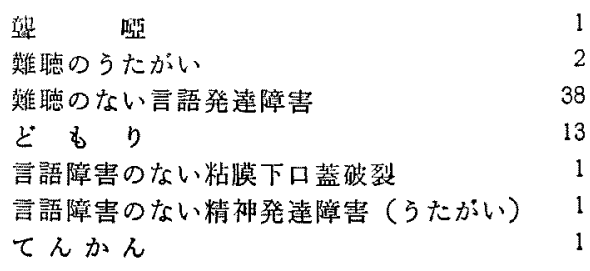

第 2 表 幼坚聴力相談室を訪れたもの

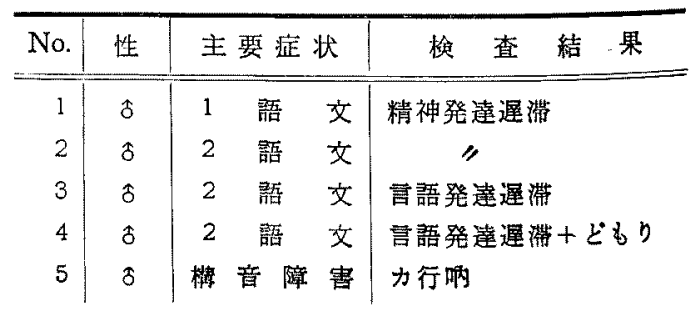


II難㯖のない言語発堛障害 (第 3 表)

これに属するものは 38 名 (3.4\%) あり，このうち亞 が2例（男1，女1）あるか゚，いずれも他医ですでに精 神薄弱と診断されていた，又1語交のものが2 例 (男) あるが，このらち1例は我↔のところで检查を行つて 精神薄弱之診断した， 2 語文は 7 例（すべて男）あり， 我々の「幼児聴力相談室」でこのうち 1 例は精神藻弱, 他の 2 例は精神発達遅滞や難㯖のない言語発達遅㴖及び

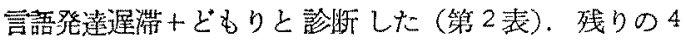
例については詳しい検查を行つてない，更に2〜3 語文 は話すことができるが長い文章やむずかしいことばがい えないといらものが10例（男8，女2）あつた．この他 発音が恶く何をしやべつているかよくわからないといら 状態のものが17 例（男12，女5）あつた。これらのう ち1例は我々のところで詳検してカ行呐之診断したが， 大部分 (13 例) は単なる 発音の 発達の遅机之思和机る わのであり，残りの4例（いずれも男）桠言語発摰掘㴖 にしばしばみられる Jargon であるか単なる発音の発達 の遅机であるか詳細に調べないと決定しか敞るすのであ つた.

難㯖き精神発迲迤滞の目立たないことぱだけの和くれ は啞から2〜3 語文迄程度は種々あり得るが，この年令

第 3 表 難聴のない言語発達障害

\begin{tabular}{|c|c|c|c|}
\hline & 男 & 女 & 部 \\
\hline $\mathrm{u}_{\mathrm{d}}$ & 1 & 1 & 2 \\
\hline 語 & 2 & 0 & 2 \\
\hline 語 & 7 & 0 & 7 \\
\hline むずかしいことばがい光ぬ & 8 & 2 & 10 \\
\hline 発音が著しく瑟 い & 12 & 5 & 17 \\
\hline iti & 30 & 8 & 38 \\
\hline
\end{tabular}

第 4 表

\begin{tabular}{|c|c|c|c|}
\hline & 男 & 女 & \\
\hline 薄 & $1($ 晒 ) & 1 (帮) & \\
\hline ts $\quad W$ & 1 (1 語文) 3 & & 4 \\
\hline 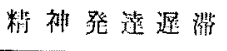 & 1 (2 浯文) & & \\
\hline 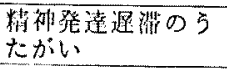 & & $1(2 \sim 3$ 活文 $)$ & 1 \\
\hline \multirow[t]{2}{*}{ 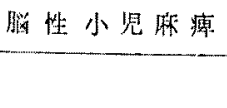 } & 1(1 語 交) & $1(2 \sim 3$ 㩆文 $)$ & 2 \\
\hline & 4 & 3 & 7 \\
\hline
\end{tabular}

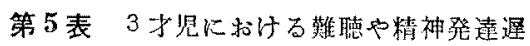

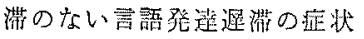

1. 1 語し語ゆつくりならいえるが文章に涰るとい 光ない。

2. 何かい出うと思つてもことばが出ないか，思5 ことか゚いえないといつた様子が双られる。

3. 辰いことばやむずかしいことばがい充ない，い

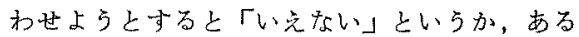
いはいやがつて逃げてしまう。

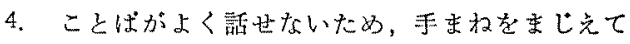
お話する。

では生理的な遅满もまだかなり存在しているものと思わ れる.しかし乍らこれ等の症例の言語の状態を钼察する 之第 5 表に示した如く各症例にるる程度共通した特街的 な症状が見受けられた。

\section{III 精神薄弱弓隠性小児麻痻}

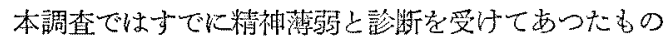

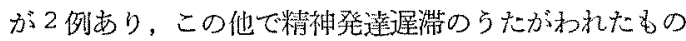

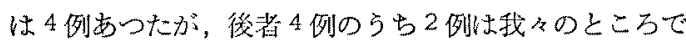
精神薄弱とした事は既に述べたところである。残りの2 例のうら1例は著明な言語障害を伴つていなかつたがこ れらについては詳しい検査をしてないので詳細は不明で ある。

脸珄小照麻痺は 2 例あつたがいずれも言語障害を伴つ ていた（第 4 表）.

$$
\mathbb{N} \text { है b } り
$$

本調查ではどもりが13 例 (1.8\%) (910，女3) あつ た、詳槒は第5表に示したが原因的にははいきりしない るのが多かつた。これらのらち言語発迋遲滞とどもりの 合併したものが 2 例あるが，このようなものはその症状 として「あのをい括らと思って子つ事って出て来ない とか「あわてると出て来ない」と挀充られている。一般 に訋胃のどもりは予後良好とされているが，これらの症

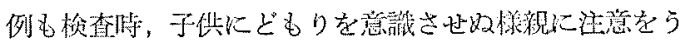

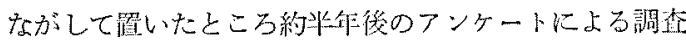
で全例加治䙷していた。

\section{第 6 表}

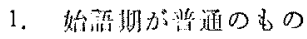

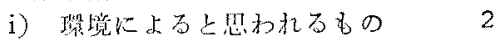

ii）原因のはつきりしないわの 7

2. 始語期が打そからた可の

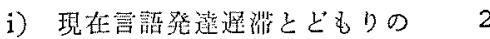
典存与るるの

ii）現在どもりだけのもの 2 


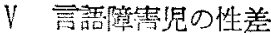

言贸障害胃が女よりも男に多いことけ今更諭ずる迄も ないが今回の調查でも男が王倒的に多く，統䛿学的にも 高度に有意である。

\section{V その他の異常児}

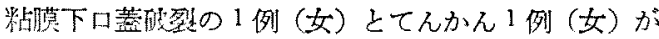
あつたが、いずれる言語障雷は伴つていなかつた。

训双生兄

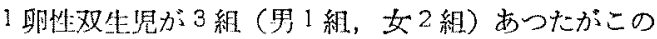

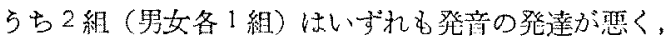
特第 1 子に比較的著明であつた。これらの双生睍のう

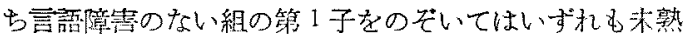
児で生れている。一般に双生罗には未熟奣が多いことは

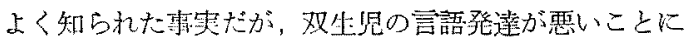
閃しては心理学の領域 16) 16)で特に注日されている独莧

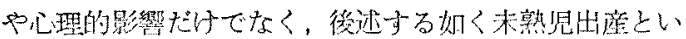

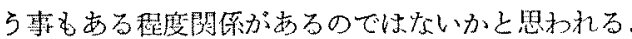

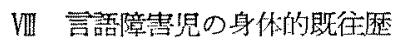

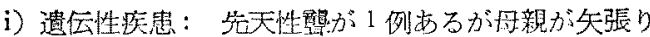

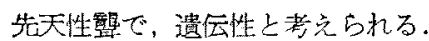

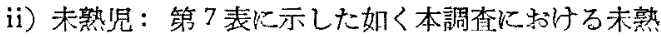
胃の頻度は1114名中87 名で $7.8 \%$ である. しかし乍ら

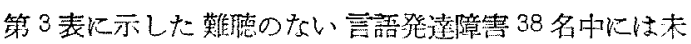

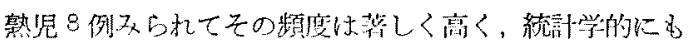

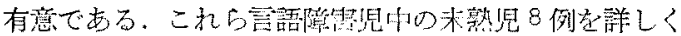

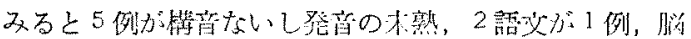

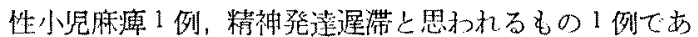
つた。

iii) 新生児仮死：新生奣仮死小1114名中32名(2.9

第 7 表

\begin{tabular}{|c|c|c|c|}
\hline 体重 & $\begin{array}{l}\text { 言語発渞㜔害 } \\
\text { のあるむの }\end{array}$ & ないもの & 計 \\
\hline 2500 以上 & 30 & 997 & 1027 \\
\hline 2500 以下 & 8 & 79 & 87 \\
\hline 部 & 38 & 1076 & 1114 \\
\hline
\end{tabular}

第 8 表

\begin{tabular}{|c|c|c|c|c|}
\hline 但 & & 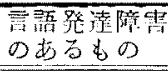 & \%いるの & 涪 \\
\hline あ & b) & 4 & 28 & 32 \\
\hline \multirow[t]{2}{*}{$\$_{5}$} & L & 34 & 1048 & 1082 \\
\hline & & 38 & 1076 & 1114 \\
\hline
\end{tabular}

\%)であつたが言語発橽障害昌 38 名中には 4 例あり，

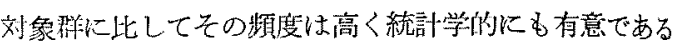
(第8表)。なおこれら4例な詳細にみると1例は隠性小

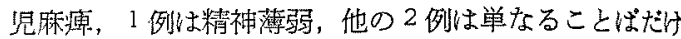
の和くれ（言語発造遅滞）であつた。

iv）鉗子分娩，莦王切開：本調查では錐子分娩が３0

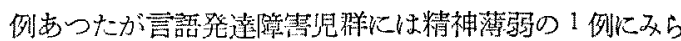
れただけであつた：㕛管王切開る 全休で18例あつたが

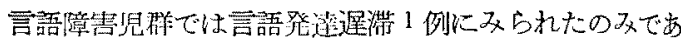
る.

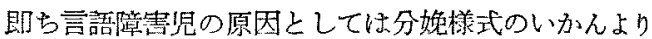
む未熟巟や仮死の有奥加重要と考光られる.

v) 出生後の疾患：加なり高度な新生罗黄道が 4 例亦

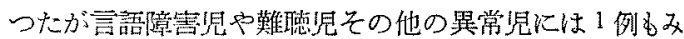
られたからた，又重篤な疾琶を経過したものは勘だ少な

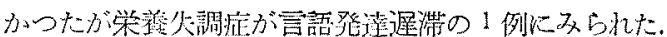

\section{考按}

I 言䟞発達障害罗の頻度

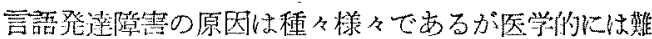

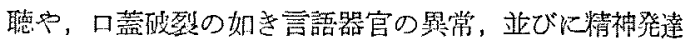

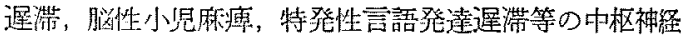
等の㜔害などが主要なるのである。著者はすでに第1及 び2 垠 17) 18)に打いて，我々の臨床を訪れた言語発羊障

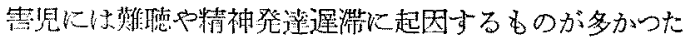

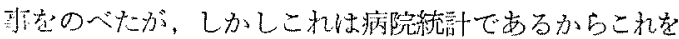

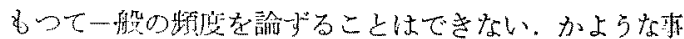

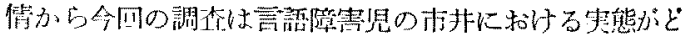
のよ5なるのであるか子知ることを1つの目的とした。

しかし乍的月 200 名程度の検查該当児があったにも拘

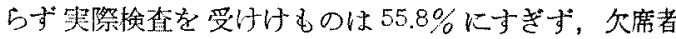
については残念作ら検植を行ら撼会を得なかつたのでこ

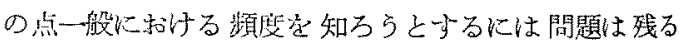

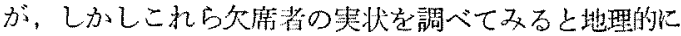
遠いとか，た专たま人手がなかつたというすのが主㑛

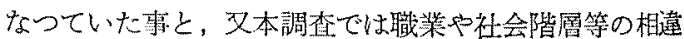
による影留け砝ど然視できることなどから考古て今回の

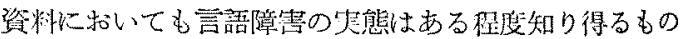
亡莑克る。

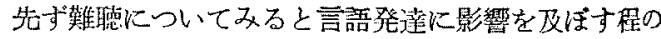

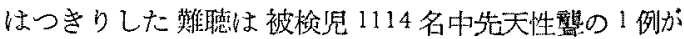

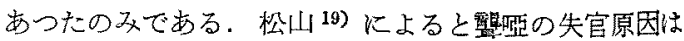
大部分は 3 才前に起つているが，本邦では大正 14 年東

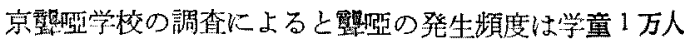


に対し平均 7.265 人となつて捛り ${ }^{200}$ ，この頻度は全世界 の平均に一票している.一方 Fröding ${ }^{21)}$ は 2000 例の新 生児の聴力検査を行い auropalpebral reflex の出なか つたものが 5 例あり，このらち 4 例は生後間もなく死 亡, 残りの1例は高度の難聴であつた事をその後の調查

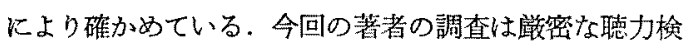
在を行つたものではないからごく軽度や1側性の難衈

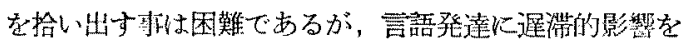

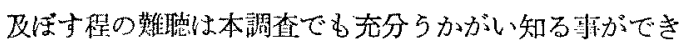
ると考党る。

一方精神薄妈は猃断の確定したものたけでも 4 例放 り、いずれも言語発達の扣くれが著明である。この頻姿 は難㯖に比べれば高いが三木等 22)によれば本邦の小学 校児童に和ける精神薄弱 (IQ 75 以下) の頻度は 4.53\%， 中学校では $7.2 \%$ であるからこれらに比べると著者の調

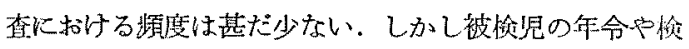
查方法が異なるので比較がもずかしい。

難㯖や著明な精神発達遅膟のない言語発達障害は3才 に篴したばかりではまだかなり存在し，3.4\%をしめて いた，その内容をみるとことばの発造がそのままおくれ ている場合と発音の発達のおくれている場合に大別でき るが，精神薄弱や脳性小児麻㿎は別として単なることば や発音の洋滞にはこの年令の 段階では Stern のいら生 理的な遅滞が少なからずあると思放れるのでこれらをす

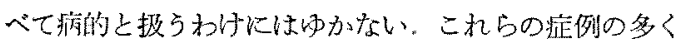
は近い将来江正常域に遙してしまうと思われるが，この 点については目下経過を観察しているので次の機会に改 めて検討してみだい。

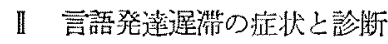

言語発達革滞の概念沉つていは筙1 1 郝17)でも触れた 如く，国によつてかなりの㯕違があり，本邦でもいるい

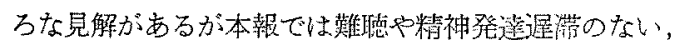
原因のはつきり把捯し難いことばの発達の就くれたもの 即ち idiopathische verzögerte Sprachentwicklung $々$ いわれるものを「言語発遟洋滞」として扱つた。

日常の諺療で言語発達障害を訴えて訪れる患者は年

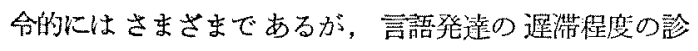
㵖には通常患者の年令に 相当寸る正常胃の 言語発達の pattern を基準にして比較する方法がとられている。 た

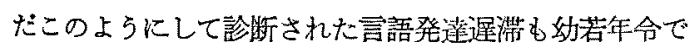
は必ずしも病的とはい克ない場合があるので, 病的であ るか否かを判断するには年令的な考慮も必要となり、ド イッ学派や鈴木 23) は3 才を過ぎても言語発達が 正常の
域炕達しない場合飞病的之报っている。

一方小見の䓂語障害の 扱い万には Mylklebust 24) 2b) のように言語の象徴的行動面からとらえようとする立場 と，先に述べた如き言語能力の発達の状㮩から把握する 行方がある。第 5 表の症状群性丁度 3 才といら時限に立 つて言語能力及び行動の雨面から把握したものである

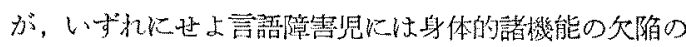

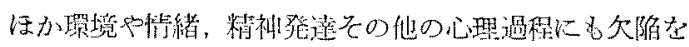

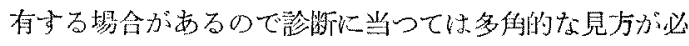
琵となる。

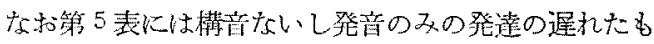
のは含めてないか゚，発潐性棈音障害しいえるような典型

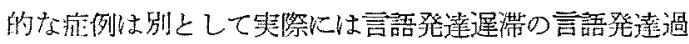
程でも满音障製が双られるので両者の区別は必ずしも明

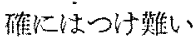

\section{III 言語匴豐览の原因}

この問題についてはすでに筑2 2郝18)で詳しくのべた ので本報でせ詳緗ははがくが，今回の調售でも言語発達

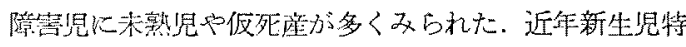
に未熟児の管理が進歩するに及んで未熟児の問題が脚光 をあびてきたが末熟览は分婏外傷や仮死，新生兄黄道等 袁招き易いといらだけでなく，未熟罗娃娠そのものにも

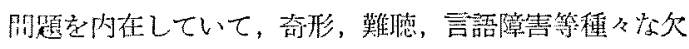

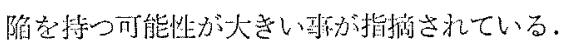

\section{結語}

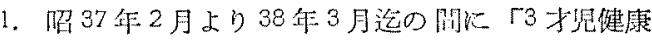

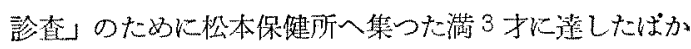

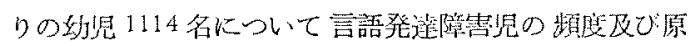

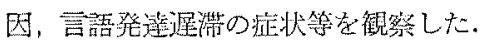

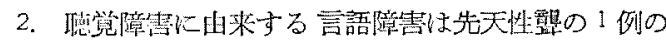
みであった。

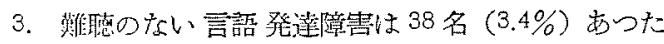

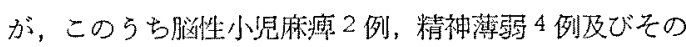
らたがいのあるもの2 例あつた。

4.どもりは13例あらた。. 原因的には環境に由来す

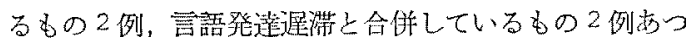
たが多くは原因不明であった。

5. 言語発洼障掣児には未熟児や仮死の頻度が省明に 高かった。

\section{文献}

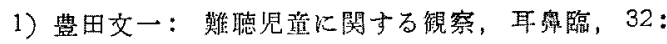
967 ，昭 12.2）阿久根等他：名古屋市蜼㯖学童聴力

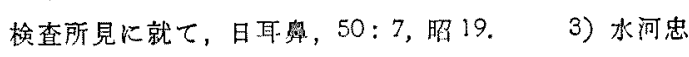


敬他：治療，34:1029, 昭 27.4) 服部啮: 聴觉の 日耳睤，66: 618，昭 38 .

19）松山信夫：熟傿の失

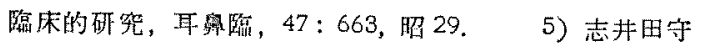
官原因について，日耳奥，59：289，昭 31 。 20) 7) $ょ$

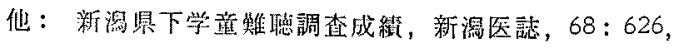
照29.65)宫島健郎：学童難聴飞関する研究（第 2 り引用。 21) Fröding, C.A.: Acoustcal Investi-

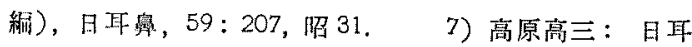
鼻全䡒，第 1 巻，第 4 册，219 面，金原出版，眧 28.

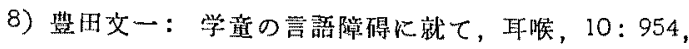

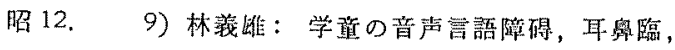
33: 570, 昭 13.10$)$ 吉田昌八: 学童の音望言語障 碍に就いて，耳涘，25：44，昭28.11）米丸年也： 学童の言語障害比関与る矿究 (第 1 報)，十全医会誌， $62 ： 96$, 昭 $34.12 ）$ 牛島義友他：乳幼児精神発澾检 查，金子書房，昭29.13) 津守真，稻毛教子：乳幼

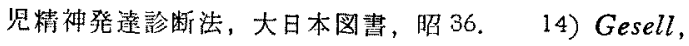
A. \& A matruda, C.S.: 発達猃断学 (佐野保, 新井清 三郎共訳)，日本小夰医事出版，昭 35.15 ) 矢田部達 郎：新版胃童の憲浯，創元社，昭31.16）阪本一郎 他：言語心理学, 学芸図菖, 昭 31. 17) 田中美鄉： 言語発䛭隚害胃の研究(第1 報)，日耳鼻，65：982，昭

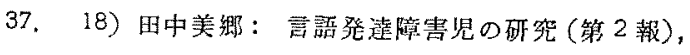
gation of Newborn Infant, Acta Otolaryng. 52: 31,

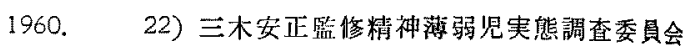
䋧：精神薄弱児の実態，59页，東大出版会，昭 37 。 23）鈴木篤郎：言語障碍の診断之治療，29頁，日本医 書, 昭 27. 24) Myklebust, H.R.: Handbook of Speech Patology, p. 503, Appleton Century Clofts (N.Y.). 1957. 25) Myklebust, H.R.: Auditory Disorders in Children, p. 143, Grume \& Stratton (N.Y.), 1954.

稿を䅂るに臨み御指導御校閲を晹つた恩的鉿 木篤郎教授，亚びに本研究の機会を与えられ释

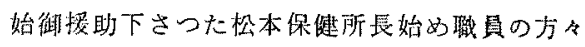
に深甚なる謝意を表します。

（原艄到着 $=$ 昭和 38.7 .1 日） 